\title{
Selected Properties of Soils for Long-Term Use in Organic Farming
}

\author{
Marcin Niemiec ${ }^{1, *}$, Maciej Chowaniak ${ }^{2}$, Jakub Sikora ${ }^{3}$, Anna Szeląg-Sikora ${ }^{3}$, \\ Zofia Gródek-Szostak ${ }^{4}$ and Monika Komorowska ${ }^{5}$
}

1 Department of Agricultural and Environmental Chemistry, Faculty of Agriculture and Economics, University of Agriculture in Krakow, Al. Mickiewicza 21, 31-120 Krakow, Poland

2 Department of Agroecology and Crop Production, Faculty of Agriculture and Economics, University of Agriculture in Krakow, Al. Mickiewicza 21,31-120 Krakow, Poland; m.chowaniak@ur.krakow.pl

3 Faculty of Production and Power Engineering, University of Agriculture in Krakow, ul. Balicka 116B, 30-149 Krakow, Poland; Jakub.Sikora@ur.krakow.pl (J.S.); Anna.Szelag-Sikora@ur.krakow.pl (A.S.-S.)

4 Department of Economics and Enterprise Organization, Cracow University of Economics, ul. Rakowicka 27, 31-510 Krakow, Poland; grodekz@uek.krakow.pl

5 Department of Vegetable and Medicinal Plants, Faculty of Biotechnology and Horticulture University of Agriculture in Krakow, Al. 29 Listopada 54, 31-425 Kraków, Poland; m.komorowska@ogr.ur.krakow.pl

* Correspondence: marcin1niemiec@gmail.com

Received: 5 February 2020; Accepted: 20 March 2020; Published: 23 March 2020

\begin{abstract}
The goal of organic farming with respect to plant production is to create high-quality products while minimizing human impacts. The aim of this paper was to assess soil properties in selected organic farms in terms of the achievement of general and specific objectives of organic farming. Fifty five (55) organic farms were selected for the research; twenty five (25) of those farms additionally had conventional animal production with cattle breeding. Soil samples were collected from each farm and, the following parameters, deciding about the suitability for agriculture were determined: $\mathrm{pH}$, content of organic carbon, available phosphorus and potassium, mineral nitrogen, and Total nitrogen content. The content of available phosphorus and mineral nitrogen was very low or low in most of the studied soils, which can lead to disturbance of homeostasis of agroecosystems. Potassium content in these soils was high. The properties of the studied soils indicate a high risk of chemical and biological degradation. Without implementing actions that control the $\mathrm{pH}$ and increase the content of nitrogen and phosphorus elements, the degradation will increase. Soil properties in the group of farms with animal production were more beneficial from the point of view of crop production, compared with farms that do not breed animals.
\end{abstract}

Keywords: organic farming; management; organic carbon; soil properties; macroelements; soil degradation; soil reaction

\section{Introduction}

Soil is one of the most important components of the environment. With respect to its functions in biomass production, carbon sequestration, organic matter decomposition, sorption and storage of mineral as well as organic compounds, it has a multifaceted effect on the natural and cultural environment [1]. Human activity associated with crop production leads to changes in soil properties, and these changes could deteriorate soil quality by hindering the productivity and functioning of natural ecosystems. Among negative aspects of agricultural intensification, attention is most often drawn to acidification, loss of organic matter, decrease in nutrient content, erosion, soil compaction, and the accumulation of xenobiotics. From the point of view of food production, soil degradation leads 
to a reduction of its production potential. As a result, the intensification of agriculture at the initial stage involves an increase in productivity due to the increasing use of production means such as fertilizers or pesticides [2,3]. Gradual soil degradation leads to decreases in yields, and to the deterioration of their technological and health quality. The biggest problem with the quality of plant products from intensive farming is the accumulation of nitrates, heavy metals, and pesticide residues. The continuous increase of food demand for a growing population requires constant expansion of areas under cultivation, the consequence of which is the reduction of the size of natural areas as well as the increasing amount of degraded soils [4]. Soils are regarded as renewable resources, but soil-forming processes last so long that, in the context of managing them, they seem to be non-renewable resources, which has received growing attention from many researchers [3-7]. A response to the intensification of farming was the creation of quality systems for the primary production (which guarantees the production of high quality products while having a minimum effect on the environment, primarily on soil) [8-12]. Organic farming is one of such systems. Despite the reduced potential of agro-ecosystems, organic farming can contribute to the improvement of physicochemical, chemical, and biological properties of soils. The prohibition on the use of mineral nitrogen fertilizers limits the eutrophication of water and the emission of greenhouse gases. Extensive agricultural production contributes to increasing the biodiversity of ecosystems. This is achieved by establishing a sustainable management system in agriculture that takes into account nature's systems and cycles, using resistant cultivars. Appropriate crop rotation makes pest control easier and improves the soil's ability to nourish plants. The use of organic fertilizers, and in special cases mineral fertilizers obtained from natural minerals are essential for maintaining soil fertility, long-term stability of plant yielding, and for balancing nutrients on a farm. One very important element is the social aspect of organic farming, which has been highlighted by Carlsson [13]. Farmers who implement the principles of integrated production gain a higher social status, have a better position in local markets, and obtain greater consumer trust. The aim of this work was to assess soil properties in selected organic farms. The quality criterion was the possibility of implementing general and specific objectives of organic farming. The following criteria were selected as the assessment parameters: $\mathrm{pH}$, organic carbon content, total nitrogen, and available forms of phosphorus and potassium.

\section{Materials and Methods}

To achieve the established research objective, i.e., to assess soil properties in the selected organic farms, 55 organic farms were studied in 2016. All the farms had been subjected to a system of control and certification of the certification body, based on inspections performed in 2015. They met the requirements of the EC regulation No. 834/2007 of 28 June 2007 titled Organic Production and Labeling of Organic Products and Repealing Regulation (EEC) No. 2092/91. All farms were converted to conduct organic production. The studied farms were located in Poland in the Dolnoślaskie (17), Lubuskie (13), and Warmińsko-Mazurskie (25) provinces (Figure 1).

Among the studied farms, 25 had conventional livestock production with cattle production. All farms that were involved in animal production were located in Warmińsko-Mazurskie province. The area of the studied farms ranged from 30 to 90 ha. A soil sample was collected from each farm, from a randomly selected field, from a 0-20 cm layer, according to the Polish Standard PN-R-04031:1997. One laboratory sample was taken per a 4 ha area. The result for one farm was the arithmetic mean of all laboratory samples taken on that farm. On all fields from which soil samples were collected, a perennial mix of grasses and small-seed legumes was grown, with different shares of legumes. The collected soil samples were air dried, sieved through a $2 \mathrm{~mm}$ sieve, and the most important parameters that indicate suitability for agriculture were determined: $\mathrm{pH}$, content of organic carbon, available phosphorus and potassium, mineral nitrogen, and total nitrogen. Soil $\mathrm{pH}$ was measured potentiometrically in a soil suspension with $1 \mathrm{M}$ of $\mathrm{dm}-3 \mathrm{KCl}$ solution, and the content of available phosphorus and potassium was determined using the Egner-Riehm method. Mineral nitrogen content was determined according to the Polish Standard PN-R-04031:1997. Mineral nitrogen was determined in a fresh soil sample, 
while other parameters were determined in an air-dry sample. Nitrogen levels were determined by elemental analysis, using a Vario Max Cube apparatus manufactured by Elementar (Table 1).

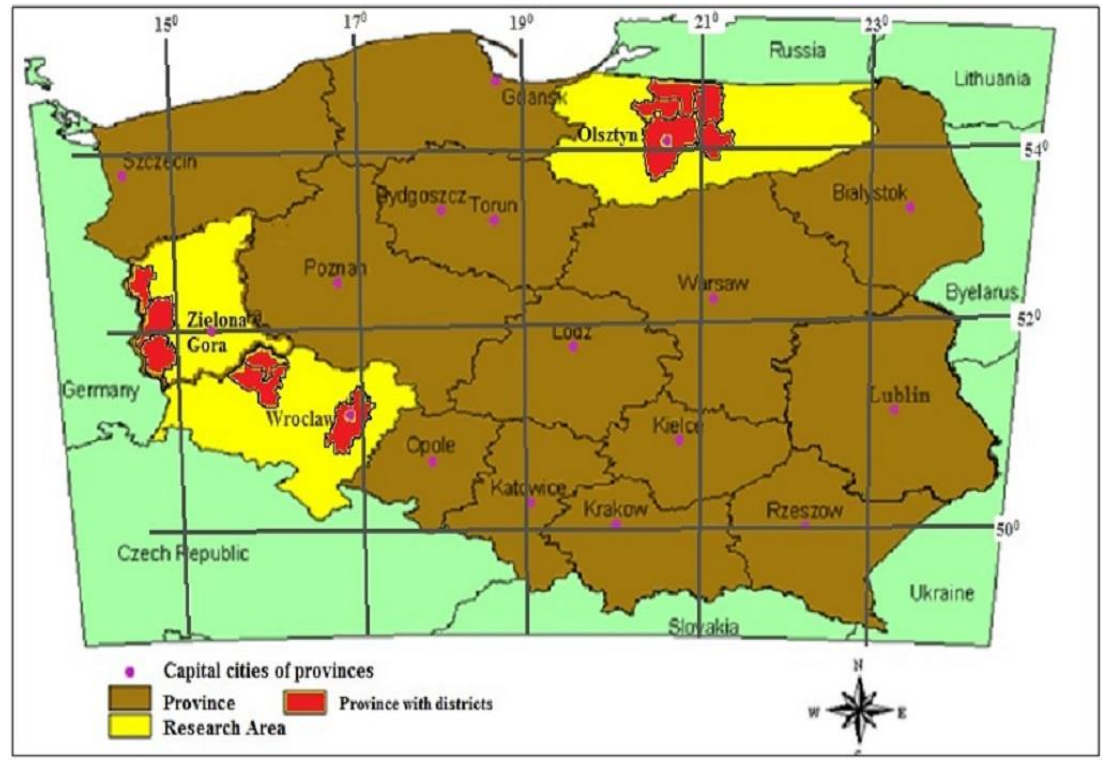

Figure 1. Map presenting the locations of the sampled farms.

Table 1. Area (ha) and type of crops in the researched farms.

\begin{tabular}{|c|c|c|c|c|c|c|c|}
\hline No. & Area of the Farm & Organic Area & Crops & No. & Area of the Farm & Organic Area & Crops \\
\hline \multicolumn{8}{|c|}{ Dolnośląskie province } \\
\hline 1 & 32.8 & 8.3 & $\mathrm{C}, \mathrm{R}, \mathrm{G}, \mathrm{S}$ & 10 & 22.5 & 4.5 & $C, R, G$ \\
\hline 2 & 38.2 & 4.6 & $\mathrm{C}, \mathrm{G}, \mathrm{O}$ & 11 & 34.3 & 7.4 & $\mathrm{C}, \mathrm{G}, \mathrm{S}$ \\
\hline 3 & 56.6 & 11.8 & $\mathrm{C}, \mathrm{R}, \mathrm{G}, \mathrm{O}$ & 12 & 38.9 & 6.12 & $\mathrm{C}, \mathrm{G}, \mathrm{O}$ \\
\hline 4 & 90.1 & 21.5 & $\mathrm{C}, \mathrm{R}, \mathrm{G}, \mathrm{S}$ & 13 & 79.5 & 24.6 & $C, G, R, S$ \\
\hline 5 & 50.9 & 16.8 & $\mathrm{C}, \mathrm{G}, \mathrm{O}$ & 14 & 88.2 & 15.2 & $C, R, G$ \\
\hline 6 & 47.5 & 6.4 & & 15 & 46.1 & 13.7 & $\mathrm{C}, \mathrm{G}, \mathrm{S}$ \\
\hline 7 & 62.6 & 32.5 & $C, R, G$ & 16 & 72.1 & 18.6 & $\mathrm{C}, \mathrm{G}, \mathrm{O}$ \\
\hline 8 & 38.5 & 12.5 & $\mathrm{C}, \mathrm{R}, \mathrm{G}$ & 17 & 49.9 & 7.7 & $C, R, G$ \\
\hline 9 & 24.6 & 5.7 & & & & & \\
\hline \multicolumn{8}{|c|}{ Lubuskie province } \\
\hline 1 & 38.2 & 4.6 & $C, R, G$ & 8 & 79.1 & 17.6 & $C, G$, \\
\hline 2 & 56.6 & 11.8 & $\mathrm{C}, \mathrm{G}, \mathrm{O}$ & 9 & 62.2 & 12.3 & $\mathrm{G}, \mathrm{O}$ \\
\hline 3 & 90.1 & 21.5 & $C, G$ & 10 & 56.8 & 11.5 & $\mathrm{G}, \mathrm{O}$ \\
\hline 4 & 50.9 & 16.8 & $C, R, G$ & 11 & 52.5 & 18.9 & $\mathrm{G}, \mathrm{O}$ \\
\hline 5 & 47.5 & 6.4 & $\mathrm{C}, \mathrm{G}, \mathrm{O}$ & 12 & 73.6 & 9.8 & $\mathrm{R}, \mathrm{G}$ \\
\hline 6 & 62.6 & 32.5 & $C, G$ & 13 & 84.6 & 23.5 & $\mathrm{C}, \mathrm{G}, \mathrm{O}$ \\
\hline 7 & 38.5 & 12.5 & $\mathrm{G}, \mathrm{O}$ & & & & \\
\hline \multicolumn{8}{|c|}{ Warmińsko-Mazurskie province } \\
\hline 1 & 62.9 & 28.9 & $\mathrm{C}, \mathrm{G}, \mathrm{M}$ & 14 & 44.2 & 19 & \\
\hline 2 & 77.5 & 52.9 & $\mathrm{C}, \mathrm{G}, \mathrm{M}$ & 15 & 33.9 & 17.5 & $\mathrm{C}, \mathrm{G}, \mathrm{M}$ \\
\hline 3 & 62.2 & 42.6 & $\mathrm{C}, \mathrm{G}, \mathrm{M}, \mathrm{O}$ & 16 & 42.6 & 22.4 & $\mathrm{C}, \mathrm{G}, \mathrm{M}$ \\
\hline 4 & 84.2 & 52.9 & $\mathrm{C}, \mathrm{G}, \mathrm{O}$ & 17 & 31.2 & 26.6 & \\
\hline 5 & 76.5 & 65.5 & $\mathrm{C}, \mathrm{G}, \mathrm{M}, \mathrm{R}$ & 18 & 30.4 & 20.7 & $\mathrm{C}, \mathrm{G}, \mathrm{M}, \mathrm{R}$ \\
\hline 6 & 43.2 & 32.5 & $C, R, G$ & 19 & 77.4 & 42.2 & $\mathrm{C}, \mathrm{G}, \mathrm{M}$ \\
\hline 7 & 52.8 & 40.5 & $\mathrm{C}, \mathrm{G}, \mathrm{M}$ & 20 & 46.6 & 31.1 & $\mathrm{C}, \mathrm{G}, \mathrm{M}$ \\
\hline 8 & 61.6 & 44.5 & $\mathrm{C}, \mathrm{G}, \mathrm{M}$ & 21 & 39.6 & 12.8 & $\mathrm{C}, \mathrm{G}, \mathrm{M}$ \\
\hline 9 & 51.4 & 39.8 & $\mathrm{C}, \mathrm{G}, \mathrm{M}$ & 22 & 62.5 & 38.4 & $\mathrm{C}, \mathrm{G}, \mathrm{M}$ \\
\hline 10 & 68.2 & 42.6 & $\mathrm{C}, \mathrm{G}, \mathrm{M}, \mathrm{R}$ & 23 & 76.1 & 43.8 & $\mathrm{C}, \mathrm{G}, \mathrm{M}, \mathrm{R}$ \\
\hline 11 & 53.5 & 36.8 & $\mathrm{C}, \mathrm{G}, \mathrm{M}$ & 24 & 83.3 & 39.2 & $\mathrm{C}, \mathrm{G}, \mathrm{M}$ \\
\hline 12 & 72.2 & 45.8 & $\mathrm{C}, \mathrm{G}, \mathrm{M}$ & 25 & 41.2 & 17.7 & $\mathrm{C}, \mathrm{G}, \mathrm{M}$ \\
\hline 13 & 84.6 & 49.8 & $\mathrm{C}, \mathrm{G}, \mathrm{M}, \mathrm{R}$ & & & & \\
\hline
\end{tabular}




\section{Statistical Analysis}

Significance of variance in the mean values was determined using Duncan's test, at the significance level of $\alpha \leq 0.05$ of mean differences among the farms without animals. The analyses were performed using the statistical software package Statistica v. 12.0 (StatSoft Inc. Tulsa, USA).

\section{Results and Discussion}

The implementation of the idea of organic farming requires farmers to have extensive knowledge of the biological, agricultural engineering, and environmental aspects of crop production. Plant cultivation without using pesticides, herbicides, fungicides, or easily soluble fertilizers is very difficult and expensive. This particularly applies to crop production on soils with low agricultural suitability or on physically, chemically, and biologically degraded soils whose natural production potential is low [14]. In the European Union, organic farming is implemented within the framework of agricultural-environmental programs. Due to potentially higher costs of organic production as well as lower yields, farmers receive subsidies. Such a system of promoting organic farming has generated a considerable increase in the area of certified crops with a very small corresponding increase in production $[15,16]$.

In many cases, farmers enter into agricultural-environmental programs only because of the subsidies; this is how they reduce costs associated with fertilization and with growing plants that reduce weeding and the development of diseases and pests. Crop production without mineral fertilization and without plant protection products leads to soil degradation, which is one of the main factors contributing to soil degradation. Farming which leads to deterioration of soil properties is contradictory to the principles of organic farming. An inappropriate approach to the problem of crop rotation and crop protection may lead to weediness and excessive development of pests or fungal diseases. Plant nutrients removed with yield must be replenished in the form of fertilization so as to prevent soil impoverishment. Rational management of organic matter resources requires organic fertilization and implementation of cultivation methods that will limit humus mineralization [17]. To maintain optimal agricultural production, particularly under conditions of management according to principles of organic farming, it is necessary to adjust soil reaction $(\mathrm{pH})$ by conducting liming $[18,19]$. Due to the way organic farming is conducted in the European Union, it is possible for ecologically used lands to undergo gradual degradation. Due to the poor demand for ecological products, and a difficult economic situation for organic farms, the use of mineral fertilization is of marginal importance [20]. Fertilization with organic fertilizers is the main source of fertilizer components and organic matter on studied organic farms. Results published by Cupiał et al. [21] indicate that the majority of organic farms in Poland do not have animal production, which translates into a lack of organic fertilization. In our research, the soil was characterized by a low agricultural value. Among the studied farms without animal production, 30 samples were classified as being sandy soils. Most of the studied farms have both ecological and conventional forms of production. On these farms, lands with the lowest agricultural suitability had been designated for organic production. Most of the studied soils, in both groups of farms, had very high acid levels or a high acidic reaction $(\mathrm{pH})$ (Table 2).

It was established that in the case with 28 samples, liming was necessary. The demand for liming was determined on the basis of the guidelines contained in the document on soil liming in Poland, issued by the Institute of Soil Science and Plant Cultivation [22]. In the case with 7 samples, liming was needed, and in the case with 10 soils, liming was recommended. The $\mathrm{pH}$ of the remaining 15 samples indicated no need for liming. No substantial difference was observed in $\mathrm{pH}$ between the group of farms with plant production (the mean value of this parameter in that group was 4.86) and the farms without crop production, with an average $\mathrm{pH}$ of 4.63 . The median value was, respectively, 4.60 and 4.54 (Table 2). Soil pH is one of the most important soil quality parameters. It affects soil biological activity, changes in humic compounds, the availability of microelements and macroelements, and also physical, physiological, chemical, and biological soil properties. To limit soil degradation, liming should be carried out in the majority of the studied farms. Organic farming should lead to the improvement of 
soil properties, but for economic reasons, liming will likely not be carried out in the studied farms during the period of conducting activities in this system (most often for a period of 5 years).

Table 2. Selected soil properties.

\begin{tabular}{lccccccc}
\hline & $\mathbf{p H}_{\mathbf{K C l}}$ & $\mathbf{P h}_{\mathbf{H} 2 \mathbf{O}}$ & $\mathbf{K}$ & $\mathbf{P}$ & $\mathbf{N} \mathbf{m i n}$ & $\mathbf{N}_{\text {tot }}$ & $\mathbf{C}_{\mathbf{o r g}}$ \\
\hline Unit & - & - & & $\mathrm{mg} \mathrm{kg}^{-1}$ & & $\mathrm{~g} \mathrm{~kg}^{-1}$ \\
\hline \multicolumn{2}{l}{ Farms with animal production } & & & & & & \\
\hline Min & 3.63 & 4.57 & 149.3 & 5.130 & 18.52 & 0.911 & 8.466 \\
Max & 6.45 & 6.95 & 908.8 & 128.0 & 89.65 & 2.113 & 20.67 \\
Mean & $4.86 \mathrm{a}$ & $5.82 \mathrm{a}$ & $343.3 \mathrm{~b}$ & $39.11 \mathrm{~b}$ & $40.56 \mathrm{~b}$ & $1.394 \mathrm{~b}$ & $14.23 \mathrm{~b}$ \\
Median & 4.60 & 5.88 & 271.0 & 37.85 & 37.11 & 1.293 & 13.59 \\
Standard deviation & 0.92 & 0.64 & 183.0 & 26.92 & 17.75 & 0.326 & 3.196 \\
Coefficient of variation & 18.96 & 11.07 & 53.31 & 68.85 & 43.76 & 23.35 & 22.39 \\
\hline Farms without animal production & & & & & & \\
\hline Min & 3.61 & 4.11 & 111.9 & 13.35 & 11.84 & 0.938 & 1.114 \\
Max & 6.18 & 6.62 & 351.3 & 45.29 & 45.73 & 1.563 & 16.71 \\
Mean & $4.63 \mathrm{a}$ & $5.46 \mathrm{a}$ & $219.5 \mathrm{a}$ & $27.26 \mathrm{a}$ & $23.34 \mathrm{a}$ & $0.925 \mathrm{a}$ & $9.837 \mathrm{a}$ \\
Median & 4.54 & 5.35 & 208.3 & 27.33 & 22.37 & 0.908 & 1.010 \\
Standard deviation & 0.69 & 0.62 & 75.48 & 7.246 & 7.533 & 0.357 & 3.925 \\
Coefficient of variation & 14.94 & 11.32 & 34.39 & 26.58 & 32.28 & 39.33 & 39.84 \\
\hline
\end{tabular}

Different letters mean statistically significant differences at the significance level $p=0.05$.

All the studied soil samples collected from the farms without animal production were observed to have a very low content of available forms of phosphorus. The content of assimilable forms of phosphorus was assessed based on the guidelines presented by Food and Agriculture Organization of the United Nations (FAO) [23]. In the case of farms with animal production, the content of this element was observed to be very low in 5 cases and low in 13 cases, while 5 soils were characterized by average content of this element. A very high content of this element was determined in two cases. It was established that the average content of this element in soils from farms that had organic crop production in conjunction with animal production was higher by approximately $30 \%$. The mean content of this element in the first group with animal production of farms amounted to $39.11 \mathrm{mg} \mathrm{P} \mathrm{kg}^{-1}$, whereas in the second group without animals, it was $27.26 \mathrm{mg} \mathrm{P} \mathrm{kg}^{-1}$ (Table 2). Phosphorus content determined in the studied soils is low and can lead to physiological starvation of plants. Klaus et al. [24] reported that inorganic phosphorus content in ecologically used pastures was at a level of approximately $11 \mathrm{mg}$ $\mathrm{P} \mathrm{kg}^{-1}$, whereas on conventional agricultural lands, the content of this element was over twice as high. The lower mineral phosphorus content determined in soil by these authors' research did not, however, translate into the content of this element visible in the yield. Phosphorus is a very important element for plant growth and development $[25,26]$. Management of phosphorus resources in soil in organic farming is particularly difficult due to the lack of fertilizers (approved for use) that contain readily available forms of this element. In organic farming, only ground phosphate rock can be used, which is a source of very poorly available phosphorus. In organic farming, the lack of organic fertilization makes it very difficult to obtain at least a zero balance of this element in soil. The gradually decreasing amount of this element in soils leads to a decrease in plant yielding and to the reduction of the possibility of atmospheric nitrogen fixation by microorganisms, which is the foundation of organic farming. The studied farms do not use mineral fertilization with phosphorus, nor are they planning to use it. In the group of farms with animal production, manure is generally used under conventional crops. Inflows of elements are associated with animal grazing on organic plots.

The mean content of available forms of potassium in the studied soils was $281.4 \mathrm{mg} \mathrm{K} \mathrm{kg}^{-1}$ and ranged between 111.9 and $908.8 \mathrm{mg} \mathrm{K} \mathrm{kg}^{-1}$. In the case of soils from farms with animal production, the level was $343.3 \mathrm{mg} \mathrm{K} \mathrm{kg}^{-1}$, whereas in the group of farms without animal production it was $219.5 \mathrm{mg} \mathrm{K} \mathrm{kg}^{-1}$. Median values were, respectively, $270.97 \mathrm{mg} \mathrm{K} \mathrm{kg}^{-1}$ and $208.26 \mathrm{mg} \mathrm{K} \mathrm{kg}^{-1}$ (Table 2). 
In all samples collected from farms dealing with animal production, a high or very high content of available forms of potassium was determined. In farms without animal production, the content of this macroelement in soils was much lower; however, the content of this element was at medium high and very high levels [23]. From the point of view of soil ecosystems, high potassium content with a very low amount of nitrogen and phosphorus is not favorable, due to an imbalance between these elements. A high potassium content can be associated with limiting the amount of plant yielding as a result of deficiencies of other elements.

Nitrogen is the most yield-forming plant nutrient; therefore, it is often used in conventional farming at quantities exceeding plant nutrient requirements. Excessive nitrogen fertilization may lead to soil acidification and intensification of the processes of eutrophication and emission of greenhouse gases. In addition, the technological quality and health of plants deteriorate in case of excessive $\mathrm{N}$ accumulation. Hence, all primary production quality systems such as GLOBAL G.A.P. (Good Agriculture Practice), Integrated Plant Production, and other systems place a great emphasis on the issue of rational fertilization, mainly with nitrogen. Organic farming does not allow the use of chemical synthesis-derived nitrogen fertilizers. Organic fertilizers may be the sole external source of this element. The main emphasis in this system is put on the use of soil ecosystem for nitrogen fixation. The use of appropriate crop rotation and accompanying agricultural engineering, with the use of plants that enrich soil with nitrogen, is the foundation of crop production in the organic system [27]. Atmospheric nitrogen fixation can be, however, disturbed in acidic soils (with inadequate structure) and in soils in which the equilibrium between elements has been disturbed [28]. The results of the current research point out at a high risk of deterioration in the quality of agro-ecosystems related to acidification and low phosphorus as well as nitrogen content in the soil, and consequently with a disturbance of the system of atmospheric nitrogen fixation [29]. The amount of nitrogen available for plants can be estimated based on the content of its mineral forms. Mineral nitrogen (Nmin) content in the studied soils was generally low. On average, Nmin content in soils in the group of farms with animal production was at a level of $40.56 \mathrm{mg} \mathrm{N} \mathrm{kg}^{-1}$, while in the farms without animal production, the content was approximately half as much, reaching the value of $23.34 \mathrm{mg} \mathrm{N} \mathrm{kg}^{-1}$. Median values for both studied groups were, respectively, 37.11 and $22.37 \mathrm{mg} \mathrm{N} \mathrm{kg}^{-1}$ (Table 2). Niemiec et al. [30] determined that mineral nitrogen content in the soil under vegetable crops was at a level of more than $300 \mathrm{mg} \mathrm{N} \mathrm{kg}^{-1}$. The low mineral nitrogen content is characteristic for ecologically used soils, which has been also highlighted by Tuomisto et al. [31] and Anglade et al. [32]. Reducing the use of nitrogen fertilizers is beneficial from the point of view of the biodiversity of habitats. Klaus et al. [22] and Chamorro et al. [33] observed a positive effect of farming according to the principles of organic farming on biodiversity on permanent pastures and arable lands. These authors emphasize, that under conditions of long-term organic production, the amount of phosphorus in soil decreases. However, too low mineral nitrogen content in soil may lead to a limited possibility of decomposition of post-harvest residues, which may lead to the development of diseases and to an increasing number of pests [34]. Moreover, if there is not enough mineral nitrogen in soil, humification processes (which are very important from the point of view of soil humus) do not take place.

The average total nitrogen content in the studied soils from farms with animal production was $1.394 \mathrm{~g} \mathrm{~kg}^{-1}$, whereas in farms without animals it was $0.911 \mathrm{~g} \mathrm{~kg}^{-1}$. Median values were, respectively, $1.293 \mathrm{~g} \mathrm{~kg}^{-1}$ and $0.908 \mathrm{~g} \mathrm{~kg}^{-1}$ (Table 2). The content of total nitrogen was low, which is characteristic for soils with low fertilization that are also low in organic matter content. The mean organic carbon content in the studied soils was $12.03 \mathrm{~g} \mathrm{~kg}^{-1}$ and ranged between 1.114 and $20.67 \mathrm{~g} \mathrm{~kg}^{-1}$. In soils from the farms with animal production, the mean carbon content was $1.423 \mathrm{~g} \mathrm{~kg}^{-1}$, while in the farms without animal production, it was $9.837 \mathrm{~g} \mathrm{~kg}^{-1}$. The organic carbon content is low and may decrease in sorption capacity, biological activity and plant feeding [35-37]. In organic farming, soil organic matter plays a special role, so actions to increases it or at least reduce its losses from soils should be prioritized.

The main purpose of organic production is to create a sustainable system of farming management. This system should take into account the cycles of the nature, as well as maintain and improve the 
health of soil, water, plants, and animals. Moreover, it should maintain and improve the balance between them, and also contribute to an increase in biodiversity. In this system, plants obtain nutrients mainly through the soil ecosystem with limited use of non-renewable resources and external means like fertilizers and plant protection products. The concept of this quality system alone does not guarantee that its implementation will result in a reduction of energy use and in reduced emissions of biogens, greenhouse gases, and xenobiotics into the environment [38]. Above all, farming in the organic system should have a permanent character and lead to improvement of soil properties under conditions of food production of high technological and sensory quality (the taste, smell, size, and color of the product).

There is a lot of information in scientific literature on the effect of organic farming on the environment $[18,37]$. Researchers of this problem emphasize that under conditions of organic production, the amount of chemical means of production introduced to soil decreases, biodiversity increases, and emissions of greenhouse gases into the atmosphere are reduced. Large agricultural machines are not used, which prevents soil compaction. Organic farming products have better technological, health, and taste properties [17,39-41]. Most results presented in scientific literature concern vegetative experiments conducted under monitored conditions, where fertilization compliant with plant requirements has been applied. In practice, it is very difficult to comprehensively implement production compliant with the principles of organic farming due to substantial costs and the need for in-depth knowledge on environmental and physiological conditions of plant growth, as well as on the biology of pests. The reduced use of external means of production surely reduces the human impact (farming) per unit of area. However, Deike et.al. [42], Mondelaers et al. [43] as well as Tuomisto et al. [31] point out that, in terms of a production unit, the effect of organic farming on the environment can be higher compared with conventional farming. Proper management of nutrients at a field and farm level is the fundamental principle that guarantees plant production without increasing soil degradation. The balance covers income of nutrients from all sources, and outgo of nutrients expressed by their quantity taken out with yield. Therefore, fertilization is an indispensable part of a rational economy, as well as in organic production [44-46]. Organic production in the all studied farms was determined by the system of subsidies and by the principles of the agricultural-environmental program. The organic crops were located on fields with the lowest agricultural suitability, on which grasses and small-seed legumes are grown owing to the fact that these crops cause the fewest technological problems during organic farming. The studied farms do not use mineral or organic fertilization. Hence, in all cases, we are dealing with a negative balance of all plant nutrients, which is indicative of a constant increase in nutrient deficiency [47-50]. Results of the conducted research point out to a high risk of degradation of the studied soils (cultivated in the organic system). The lack of fertilization results in an increasing phosphorus deficit, which may lead to a reduction of soil biological activity and reduce possibilities of atmospheric nitrogen fixation caused by microorganisms. Nitrogen deficiency limits the ability of soil microorganisms to decompose plant and animal remains. In farms conducting crop and animal production, the soil abundance in biogenic elements was slightly higher, but insufficient for proper functioning of the ecosystem. To determine the actual effect of organic farming on the environment, while taking into account habitat, economic, and cultural aspects, studies should be carried out on farms with this production for many years [51,52].

\section{Conclusions}

The results of the conducted research indicate a high risk of soil degradation under organic production in the studied area. Insufficient amounts of used production means may lead to acidification and soil sterilization. All the studied farms had plant production, both in the ecological and conventional systems. The organic crops were located on soils of the lowest agricultural suitability. All the studied soils showed a very low quantity of organic carbon. They were also characterized by very low $\mathrm{pH}$. In most cases, the soils were classified as highly acidic soils. The content of available phosphorus and mineral nitrogen was very low or low in most of the studied soils, which can lead to disturbance of the homeostasis of agroecosystems. Potassium content in these soils was generally high. The properties of 
the studied soils point to a high risk of degradation. Active measures are necessary to limit acidification and the deficit of elements. In order to manage organic production effectively, and to meet the general and specific objectives of organic farming, greater attention should be paid to soil resource management issues in the context of maintaining a high level of fertility in the broad sense.

Author Contributions: Conceptualization, M.N., M.C., M.K.; methodology J.S., A.S.-S, M.N., Z.G.-S.; validation, A.S.-S., M.K. and Z.G.-S.; formal analysis, M.N., M.C., M.K.; resources, J.S., A.S.-S., M.N., Z.G.-S.; data curation, A.S.-S., M.K.; writing —original draft preparation, M.K., M.C., Z.G.-S.; visualization, M.N., M.C., M.K. All authors have read and agreed to the published version of the manuscript.

Funding: This research was funded by the Ministry of Science and Higher Education of the Republic of Poland.

Acknowledgments: This research was funded by the Ministry of Science and Higher Education of the Republic of Poland.

Conflicts of Interest: The authors declare no conflict of interest.

\section{References}

1. Dec, D. Assessment of the microbiological activity in agricultural and urban soils. Soil Sci. Ann. 2014, 65, 156-160. [CrossRef]

2. Sándor, G.; Szabó, G. Influence of human activities on the soils of Debrecen, Hungary. Soil Sci. Ann. 2014, 65, 2-9. [CrossRef]

3. Lorenz, K.; Lal, R. Chapter three-Environmental impact of organic agriculture. Adv. Agron. 2016, 139, 99-152.

4. Tuomisto, H.L.; Hodge, I.D.; Riordan, P.; Macdonald, D.W. Exploring a safe operating approach to weighting in life cycle impact assessment e a case study of organic, conventional and integrated farming systems. J. Clean. Prod. 2012, 37, 147-153. [CrossRef]

5. Schiefer, J.; Georg, J.; Lair, G.J.; Blum, W.E.H. Potential and limits of land and soil for sustainable intensification of European agriculture. Agric. Ecosyst. Environ. 2016, 230, 283-293. [CrossRef]

6. Willekens, K.; Vandecasteele, B.; Buchan, D.; Neveb, S. Soil quality is positively affected by reduced tillage and compost in an intensive vegetable cropping system. Appl. Soil Ecol. 2014, 82, 61-71. [CrossRef]

7. Craheix, D.; Angevin, F.; Reau, R.; Bergez, J.É.; Bockstaller, C.; Doré, T.; Guichard, L.; Colomb, B. MASC, a model to assess the sustainability of cropping systems: Taking advantage of feedback from first users. In Proceedings of the XIIth Congress of the European Society for Agronomy, Helsinki, Finland, 20-24 August 2012; pp. 282-283.

8. Sikora, J.; Niemiec, M.; Szelag-Sikora, A. Evaluation of the chemical composition of raw common duckweed (Lemna minor L.) and pulp after methane fermentation. J. Elem. 2018, 23, 685-695.

9. Niemiec, M.; Komorowska, M.; Szelag-Sikora, A.; Sikora, J.; Kuboń, M.; Gródek-Szostak, Z.; Kapusta-Duch, J. Risk assessment for social practices in small vegetable farms in Poland as a tool for the optimization of quality management systems. Sustainability 2019, 11, 3913. [CrossRef]

10. Niemiec, M.; Sikora, J.; Szelagg-Sikora, A.; Kuboń, M.; Stuglik, J.; Komorowska, M. Ocena składu chemicznego glonów brunatnych z antropogenicznie przekształconych rejonów Morza Czarnego w kontekście możliwości wytwarzania z nich nawozów. Przemysł Chemiczny 2019, 98, 1000-1003. [CrossRef]

11. Gródek-Szostak, Z.; Malik, G.; Kajrunajtys, D.; Szelag-Sikora, A.; Sikora, J.; Kuboń, M.; Niemiec, M.; Kapusta-Duch, J. Modeling the dependency between extreme prices of selected agricultural products on the derivatives market using the linkage function. Sustainability 2019, 11, 4144. [CrossRef]

12. Szelag-Sikora, A.; Sikora, J.; Niemiec, M.; Gródek-Szostak, Z.; Kapusta-Duch, J.; Kuboń, M.; Komorowska, M.; Karcz, J. Impact of integrated and conventional plant production on selected soil parameters in carrot production. Sustainability 2019, 11, 5612. [CrossRef]

13. Carlsson, F.; Khanh Nam, P.; Linde-Rahr, M.; Martinsson, P. Are Vietnamese farmers concerned with their relative position in society? J. Dev. Stud. 2007, 43, 1177-1188. [CrossRef]

14. Mehmod, T.; Hussain, S.; Farooq, U.; Akram, K. Impact of different farming systems (conventional, integrated and organic) and storage time on physiological characteristics of kinnow mandarin. (Citrus nobilis $\times$ Citrus deliciosa). Pak. J. Agric. Sci. 2016, 53, 7-15. 
15. Argyropoulos, C.; Tsiafouli, M.A.; Sgardelis, S.P.; Pantis, J.D. Organic farming without organic products. Land Use Policy. 2013, 32, 324-328. [CrossRef]

16. Wahlhütter, S.; Vogla, C.R.; Eberhart, H. Soil as a key criteria in the construction of farmers' identities: The example of farming in the Austrian province of Burgenland. Geoderma 2016, 269, 39-53. [CrossRef]

17. Hasegawa, H.; Furukawa, Y.; Kimura, S.D. On-farm assessment of organic amendments effects on nutrient status and nutrient use efficiency of organic rice fields in Northeastern Japan. Agric. Ecosyst. Environ. 2005, 108, 350-362. [CrossRef]

18. Sacco, D.; Moretti, B.; Monaco, S.; Grignani, C. Six-year transition from conventional to organic farming: Effects on crop production and soil quality. Eur. J. Agron. 2015, 69, 10-20. [CrossRef]

19. Sánchez de Cima, D.; Luik, A.; Reintam, E. Organic farming and cover crops as an alternative to mineral fertilizers to improve soil physical properties. Int. Agrophys. 2015, 29, 405-412. [CrossRef]

20. Krause, J.; Spicka, J. Analisys of economic performance ond opportunities for the development of organic farming: Case study of the Czech Republic. Pak. J. Agric. Sci. 2017, 54, 717-724.

21. Cupiał, M.; Klimas, A.; Szelag-Sikora, A.; Niemiec, M.; Sikora, J. Problem of management of nutrients in organic farms (Pl). Proc. ECOpole 2013, 7, 553-559.

22. Hołubowicz-Kliza, G. Wapnowanie gleb w Polsce. Instrukcja wdrożeniowa nr 128; Wydawnictwo IUNG-PIB: Puławy, Poland, 2006.

23. FAO. Fertilizer Use by Crop in Poland; Food and Agriculture Organization of the United Nations: Rome, Italy, 2003.

24. Klaus, V.H.; Kleinebecker, T.; Prat, D.; Gossner, M.M.; Boc, A.F.; Gockel, S.; Hemp, A.; Lange, M.; Müller, J.; Oelmann, Y.; et al. Does organic grassland farming benefit plant and arthropod diversity at the expense of yield and soil fertility? Agric. Ecosyst. Environ. 2013, 177, 1-9. [CrossRef]

25. Pizzeghello, D.; Schiavon, M.; Maretto, L.; Stevanato, P.; Ertani, A.; Altissimo, A.; Nardi, S. Short-term application of polymer-coated mono-ammonium phosphate in a calcareous soil affects the pools of available phosphorus and the growth of Hypericum $\times$ moserianum (L.). Front. Sustain. Food Syst. 2019, 3, 4. [CrossRef]

26. Pizzeghello, D.; Berti, A.; Nardi, S.; Morari, F. Relationship between soil test phosphorus and phosphorus release to solution in three soils after long-term mineral and manure application. Agric. Ecosyst. Environ. 2016, 233, 214-223. [CrossRef]

27. Hajduk, E.; Właśniewski, S.; Szpunak-Krok, E. Influence of legume crops on content of organic carbon in sandy soil. Soil Sci. Ann. 2015, 66, 52-56. [CrossRef]

28. Yan, Z.; Shuo, S.; Li, J.; Alva, A. Qing chena manure and nitrogen application enhances soil phosphorus mobility in calcareous soil in greenhouses. J. Environ. Manag. 2016, 181, 26-35. [CrossRef]

29. Niemiec, M.; Sikora, J.; Szelag-Sikora, A. Evaluation of method production in terms of implementation of organic farming in Poland. J. Res. Appl. Agric. Eng. 2016, 61, 72-76.

30. Niemiec, M.; Szelag-Sikora, A.; Cupiał, M. Evaluation of the efficiency of celeriac fertilization with the Use of Slow-acting Fertilizers. Agric. Sci. Proc. 2015, 7, 177-183. [CrossRef]

31. Tuomisto, H.L.; Hodge, I.D.; Riordan, P.; Macdonald, D.W. Does organic farming reduce environmental impacts? A meta-analysis of European research. J. Environ. Manag. 2012, 112, 309-320. [CrossRef]

32. Anglade, J.; Billen, G.; Garnier, J.; Makridis, T.; Puech, T.; Tittel, C. Nitrogen soil surface balance of organic vs conventional cash crop farming in the Seine watershed. Agric. Syst. 2015, 139, 82-92. [CrossRef]

33. Chamorro, L.; Masalles, R.M.; San, F.X. Arable weed decline in Northeast Spain: Does organic farming recover functional biodiversity? Agric. Ecosyst. Environ. 2016, 223, 1-9. [CrossRef]

34. Finn, D.; Page, K.; Catton, K.; Strounina, E.; Kienzle, M.; Robertson, F.; Armstrong, R.; Dalal, R. Effect of added nitrogen on plant litter decomposition depends on initial soil carbon and nitrogen stoichiometry. Soil Biol. Biochem. 2015, 91, 160-168. [CrossRef]

35. Kuziemska, B.; Wieremiej, W.; Jaremko, D.; Bik, B.; Trębicka, J.; Klej, P. Effect of liming and addition of organic materials to the nickel content in biomass of cocksfoot and his fractions in soil contaminated with this element. Soil Sci. Ann. 2015, 66, 10-16. [CrossRef]

36. Zhang, Z.; Qiang, H.; McHugh, A.D.; He, J.; Li, H.; Wang, Q.; Lu, Z. Effect of conservation farming practices on soil organic matter and stratification in a mono-cropping system of Northern China. Soil Tillage Res. 2016, 156, 173-181. [CrossRef]

37. Shahzad, K.; Khan, A.; Richards, M.; Smith Jo, U. The impact of treatment of organic manures on future soil carbon sequestration under different tillage systems in Pakistan. Pak. J. Agric. Sci. 2017, 54, 277-286. 
38. Król, A.; Lipiec, J.; Turski, M.; Kuś, J. Effects of organic and conventional management on physical properties of soil aggregates. Int. Agrophys. 2013, 27, 15-21.

39. Lee, K.S.; Choe, Y.C.; Park, S.H. Measuring the environmental effects of organic farming: A meta-analysis of structural variables in empirical research. J. Environ. Manag. 2015, 162, 263-274. [CrossRef]

40. Deria, A.M.; Bell, R.W.; O'Hara, G.W. Organic wheat production and soil nutrient status in a Mediterranean climatic zone. J. Sustain. Agric. 2003, 21, 21-47. [CrossRef]

41. Rusch, A.; Delbac, L.; Muneret, L.; Thiéry, D. Organic farming and host density affect parasitism rates of tortricid moths in vineyards. Agric. Ecosys. Environ. 2015, 214, 46-53. [CrossRef]

42. Deike, S.; Pallutt, B.; Christen, O. Investigations on the energy efficiency of organic and integrated farming with specific emphasis on pesticide use intensity. Eur. J. Agron. 2008, 28, 461-470. [CrossRef]

43. Mondelaers, K.; Aertsens, J.; Van Huylenbroeck, G. A meta-analysis of the differences in environmental impacts between organic and conventional farming. Br. Food J. 2009, 111, 1098-1119. [CrossRef]

44. Craheix, D.; Angevin, F.; Doré, T.; de Tourdonnet, S. Using a multicriteria assessment model to evaluate the sustainability of conservation agriculture at the cropping system level in France. Eur. J. Agron. 2016, 76, 75-86. [CrossRef]

45. Kuźnia, M.; Wojciech, J.; Łyko, P.; Sikora, J. Analysis of the combustion products of biogas produced from organic municipal waste. J. Power Technol. 2015, 95, 158-165.

46. Kasprzak, K.; Wojtunik-Kulesza, K.; Oniszczuk, T.; Kuboń, M.; Oniszczuk, A. Secondary metabolites, dietary fiber and conjugated fatty acids as functional food ingredients against overweight and obesity. Nat. Prod. Commun. 2018, 13, 1073-1082. [CrossRef]

47. Gródek-Szostak, Z.; Szelag-Sikora, A.; Sikora, J.; Korenko, M. Prerequisites for the cooperation between enterprises and business supportinstitutions for technological development. In Business and Non-Profit Organizations Facing Increased Competition and Growing Customers' Demands; Wyższa Szkoła Biznesu-National-Louis University: Nowy Sacz, Poland, 2017; Volume 16, pp. 427-439.

48. Niemiec, M.; Komorowska, M.; Szelag-Sikora, A.; Sikora, J.; Kuzminova, N. Content of Ba, B, Sr and As in water and fish larvae of the genus Atherinidae L. sampled in three bays in the Sevastopol coastal area. J. Elem. 2018, 23, 1009-1020. [CrossRef]

49. Cupiał, M.; Szelag-Sikora, A.; Niemiec, M. Farm machinery and processes management in sustainable agriculture. In Proceedings of the 7th International Scientific Symposium: Symposium Proceedings, Gembloux, Belgium, 25-27 November 2015.

50. Szelag-Sikora, A.; Niemiec, M.; Sikora, J.; Chowaniak, M. Possibilities of designating swards of grasses and small-seed legumes from selected organic farms in Poland for feed. In Proceedings of the IX International Scientific Symposium “Farm Machinery and Processes Management in Sustainable Agriculture”, Lublin, Poland, 22-24 November 2017; pp. 365-370.

51. Sikora, J.; Niemiec, M.; Szelag-Sikora, A.; Kuboń, M.; Olech, E.; Marczuk, A. Zgazowanie odpadów z przemysłowego przetwórstwa karpia. Przem. Chem. 2017, 96, 2275-2278. [CrossRef]

52. Sikora, J.; Niemiec, M.; Tabak, M.; Gródek-Szostak, Z.; Szelagg-Sikora, A.; Kuboń, M.; Komorowska, M. Assessment of the efficiency of nitrogen slow-release fertilizers in integrated production of carrot depending on fertilization strategy. Sustainability 2020, 12, 1982. [CrossRef]

(C) 2020 by the authors. Licensee MDPI, Basel, Switzerland. This article is an open access article distributed under the terms and conditions of the Creative Commons Attribution (CC BY) license (http://creativecommons.org/licenses/by/4.0/). 